\title{
Pushing the detection limits: strategies towards highly sensitive optical-based protein detection
}

\author{
Nikan Momenbeitollahi ${ }^{1} \cdot$ Teran $^{\text {Cloet }}{ }^{1}$ Huiyan $\mathrm{Li}^{1}$ \\ Received: 12 June 2021 / Revised: 14 July 2021 / Accepted: 19 July 2021 / Published online: 6 August 2021 \\ (C) Springer-Verlag GmbH Germany, part of Springer Nature 2021
}

\begin{abstract}
Proteins are one of the main constituents of living cells. Studying the quantities of proteins under physiological and pathological conditions can give valuable insights into health status, since proteins are the functional molecules of life. To be able to detect and quantify low-abundance proteins in biofluids for applications such as early disease diagnostics, sensitive analytical techniques are desired. An example of this application is using proteins as biomarkers for detecting cancer or neurological diseases, which can provide early, lifesaving diagnoses. However, conventional methods for protein detection such as ELISA, mass spectrometry, and western blotting cannot offer enough sensitivity for certain applications. Recent advances in optical-based micro- and nanobiosensors have demonstrated promising results to detect proteins at low quantities down to the single-molecule level, shining lights on their capacities for ultrasensitive disease diagnosis and rare protein detection. However, to date, there is a lack of review articles synthesizing and comparing various optical micro- and nano-sensing methods of enhancing the limits of detections of the antibody-based protein assays. The purpose of this article is to critically review different strategies of improving assay sensitivity using miniaturized biosensors, such as assay miniaturization, improving antibody binding capacity, sample purification, and signal amplification. The pros and cons of different methods are compared, and the future perspectives of this research field are discussed.
\end{abstract}

Keywords Protein quantification $\cdot$ Assay sensitivity $\cdot$ Miniaturization $\cdot$ Antibody binding capacity $\cdot$ Signal enhancement $\cdot$ Sample purification

\section{Introduction}

Proteins are the fundamental constituents of living cells performing numerous essential cellular functions [1]. Studying the proteins expressed during stressful conditions and environments can allow for valuable insights into health and diseases. This is because through dynamic alteration, proteins express changes caused by these stressful conditions, which can include failing to function properly and over- or underexpression. Therefore, determining the proteins expressed in cells, tissues, or those secreted into the body circulation can provide the information about the conditions of the health and disease [1].

Huiyan Li

huiyanli@uoguelph.ca

1 School of Engineering, University of Guelph, Guelph, Ontario N1G 2W1, Canada
Some biofluids commonly used to detect proteins include blood plasma, serum, saliva, and urine. Blood plasma or serum can be easily obtained through venepuncture and has a high protein content, which can contain comprehensive information from different organs due to circulation in the body [2]. Saliva contains fluids secreted from glands within the oral cavity, as well as some peptides found in blood. It has a smaller range of proteins than serum or plasma, which makes it easier to analyze for some specific analytes, and is easily obtainable. Urine is also less biologically complex than plasma; however, it still contains a large range of proteins [2].

For many applications such as early disease diagnostics, highly sensitive protein detection methods are required, as the concentrations of the disease-related proteins can be low in the biofluid samples. For example, early detection of cancer proteins can be lifesaving, and can predict the patients' response to therapies [3]. For the detection of neurological disorders, while several biomarkers have been identified in cerebrospinal fluid, only a small number of brain-derived proteins pass through the blood-brain barrier into circulation, requiring 
highly sensitive techniques to detect these biomarkers [4]. In addition, single molecule detection has become especially important when measuring molecules present in extremely low quantities or when studying the molecular heterogeneity between cohorts [5]. Understanding the protein heterogeneity at a single-cell level in tumor cells can help with early detection and effective treatment, as cancer cells have shown large molecular variations among populations $[6,7]$.

Conventional methods for protein quantification may suffer limited assay sensitivity, which makes the detection of the low-abundance proteins difficult [3]. For example, since its development in 1971, conventional ELISA has been one of the main technologies for quantifying proteins in research and clinical laboratories [8]. In a sandwich format performed with a 96-well plate, capture antibody is immobilized onto the bottom of each well, followed by a blocking step and sample incubation. Detection antibody is then applied and signal reporters are added for signal generation. In each step, 100-200 $\mu \mathrm{L}$ of reagent is required. However, in early cancer diagnosis using conventional ELISA, a tumor may have grown for 10.6 to 12.6 years to a size of $25.36 \mathrm{~mm}$ before it is detectable [9]. This is because for early detection of many cancers, the potential protein biomarker concentrations in serum could range from low $\mathrm{ng} / \mathrm{mL}$ to below $1 \mathrm{pg} / \mathrm{mL}$. However, with conventional ELISA's sensitivity, it is difficult to achieve the low pg/ $\mathrm{mL}$ range for many proteins, which is not sensitive enough for earlier cancer detection [10]. Other methods such as conventional western blotting and mass spectrometry are also used for protein detection, and typically, the limit of detection (LOD) for both methods is in the high $\mathrm{ng} / \mathrm{mL}$ range $[8,11$, 12]. In particular, western blotting is an antibody-based protein detection technique, in which proteins are separated in a gel by size, transferred onto a membrane, and detected with a primary antibody followed by a secondary antibody for signal production. Therefore, it is important to develop highly sensitive, and ideally multiplexed methods of protein detection to meet the needs in biological and biomedical applications.

Recently, advances in optical-based micro- and nanobiosensors have shown promise in making ultrasensitive assays for detecting proteins at attomolar concentrations [8]. These technologies mainly rely on antibody-based protein detection, i.e., using antibodies to bind and capture specific protein targets for analysis [13-15]. However, so far there has been a lack of review articles on summarizing and classifying different strategies for improving the assay sensitivity, and on comparing the pros and cons of various technologies. Instead of a comprehensive review, the purpose of this article is to bridge this gap by highlighting the common strategies used in optical micro- and nano-biosensors towards recent efforts of improving the sensitivity of protein assays, together with the critical analysis of each method, thereby discussing the future directions of this research field. Specifically, we will first discuss effective miniaturization technologies, such as assay miniaturization on 2D surfaces or in $3 \mathrm{D}$ microchannels and microwells, followed by demonstrating methods of improving antibody binding capacity and sample purification, as well as reviewing signal amplification methods. Some literatures included in this article applied a combination of more than one strategy to improve the assay sensitivity, in which case we will specify each of the strategies used and their working principles.

\section{Assay miniaturization}

Miniaturization of the antibody-based protein assays allows for enriching and concentrating the target proteins into a small volume or region, thus enabling stronger signals to achieve high assay sensitivity [16]. In addition, assay miniaturization reduces the diffusion distance of the reagent molecules as opposed to the distances present in large volumes, resulting in higher antibody-antigen binding efficiency and shorter assay time [17]. Other advantages of miniaturized assays are reduced costs and lower levels of invasiveness, as less sample volumes need to be obtained [18].

\section{Assay miniaturization on 2D surfaces}

Protein or antibody microarrays have been developed to miniaturize conventional immunoassays from 96 -well plates to microscale spots on a chip $[19,20]$. This method can offer advantages such as low reagent and antibody consumption, high sensitivity, and multiplexity [19]. Through miniaturization of the assay spots and thus concentrating the analyte molecules into micro-scale dimensions for signal production, antibody microarrays have been able to provide a LOD in the ng/ $\mathrm{mL}$ or even middle $\mathrm{pg} / \mathrm{mL}$ range [21]. The technology and applications of the "standard" protein or antibody microarrays have been previously reviewed [22-24]. In this article, we will discuss several recent innovations of the antibody microarrays towards improving the assay sensitivity.

Zhang et al. developed an optically enhanced protein microarray (OEPM) platform using a layer of antibodies on a metal film [25]. They were separated by an 80-nm dielectric spacer to provide a strong signal enhancement based on the metalenhanced fluorescence mechanism [26]. The antigen was captured by the antibody on the surface, recognized by the fluorescently tagged detection antibody, and monitored by scanning microscopy to measure the fluorescence. Five protein markers-IL-1 beta, IL-6, EMMPRIN/CD147, MMP, and VEGF - were selected to test this method, and the LODs of $1.1 \mathrm{pg} / \mathrm{mL}, 1.6 \mathrm{pg} / \mathrm{mL}, 4.5 \mathrm{pg} / \mathrm{mL}, 230 \mathrm{pg} / \mathrm{mL}$, and $12 \mathrm{pg} / \mathrm{mL}$ were shown, respectively. This method improved sensitivity by 2-10 times compared with those of the commercial ELISAs and 2D-glass slide-based microarrays for protein quantification, due to a combination of assay miniaturization in a microarray format 
and a metal-enhanced fluorescence method (more details will be discussed in the "Surface enhancement techniques" section) [25].

Taking advantage of a fluorescence-based assay, Verardo et al. developed a single chain fragment variable ( $\mathrm{scFv}$ ) antibody-based microarray platform consisting of $\mathrm{SiO}_{2}$-coated $\mathrm{GaP}$ nanowires [27]. Protein markers such as CEACAM-1, IL-5, and MCP-1were measured. The fabricated nanowires had an axial length of $4.1 \pm 0.1 \mu \mathrm{m}$ and a radial diameter of $160 \pm 7 \mathrm{~nm}$. The assay procedure is illustrated in Fig. 1. It was shown that when using nanowires as reaction substrates, the total fluorescent signal intensity and the signal to noise ratio (SNR) were enhanced by more than one order of magnitude compared to flat substrates. This enhancement was a combined effect from (i) assay miniaturization into micro-spots that enriched analyte molecules, (ii) fluorescence signal enhancement by nanowires, and (iii) large reaction surface provided by nanowires compared to $2 \mathrm{D}$ surface that helped enrich more target molecules from samples. The assay showed a more quantifiable signal at low protein concentrations in serum samples, leading to a lower LOD. For example, for the MCP-1 protein, a concentration on the order of $100 \mathrm{pg} / \mathrm{mL}$ was found in serum, while for IL-5 it was on the order of 10 $\mathrm{pg} / \mathrm{mL}$. The prospect of a LOD below $1 \mathrm{pg} / \mathrm{mL}$ (i.e., $\sim 10-100$ $\mathrm{fM}$ ) raised the sensitivity by 20 -fold compared to conventional ELISA, making it a state-of-the-art immunoassay [27]. This method however did require additional steps and reagents to synthesize the nanowires and the array, making it inconvenient and less economical to use for wider applications.
Li et al. developed an immunoassay microarray using $\mathrm{TiO}_{2}$-porous silicon (TiO2-PSi) material to detect multiplex mycotoxins [28]. The large internal surface area of the PSi allowed accommodating many probe molecules; together with the assay miniaturization strategy for molecular enrichment, this platform was able to enhance the SNR and the detection sensitivity. To modify the surface of the $\mathrm{TiO}_{2}-\mathrm{PSi}$ wafer to immobilize the antigens of mycotoxins, epoxy groups were selected and used to modify the surface. Fluorescence intensity was measured to determine the concentration of the samples. This method showed detection ranges of $0.01-1 \mathrm{ng} / \mathrm{mL}$ for OTA, $0.001-1 \mathrm{ng} / \mathrm{mL}$ for AFB1, and $0.01-1 \mathrm{ng} / \mathrm{mL}$ for FB1 [28].

\section{Assay miniaturization in 3D microchannels and microwells}

Microchannels and microwells have been developed via microfluidic technology, which is a miniaturization method that allows for the transport of small amounts of fluid (picoto microliter volume) throughout a biochip [29, 30]. Shadfan et al. used four markers for the early detection of ovarian cancer in a multiplexed, programmable bio-nano-chip (pBNC) device [31]. The device included a $4 \times 5$ array of agarose microbeads with capture antibodies anchored on them at a concentration of $320 \mathrm{ng}$ per bead. The chip was integrated with automatic sample metering, debris removal, storage of reagents, and waste disposal. The assay was performed on the
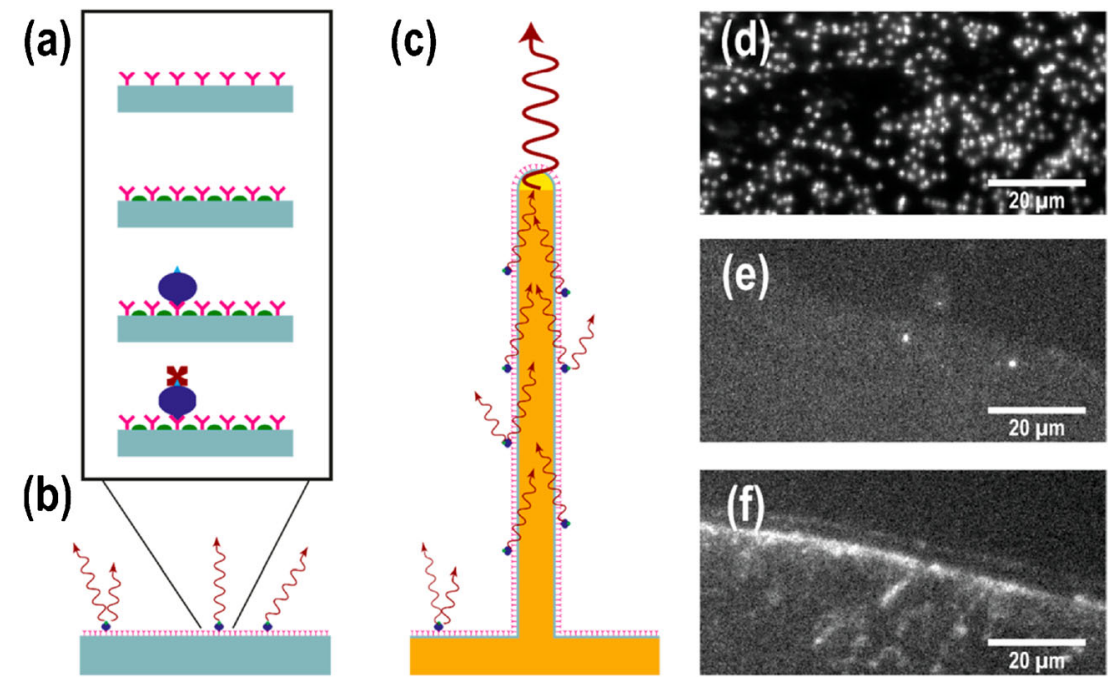

Fig. 1 (a) A schematic of the single chain fragment variable ( $\mathrm{scFv}$ ) assay. First, the ScFv antibodies (shown in pink) were physiosorbed on the surface. The blocking agent (shown in green) was then utilized to reduce unspecific binding of biotinylated serum proteins (shown in blue). These serum proteins were targeted by fluorescently labelled streptavidin (shown in dark red). (b, c) A schematic of the assay on a flat substrate can be seen in (b) as well as a light-guiding nanowire substrate. (c) The supported waveguides to be reemitted at the tip were excited by the emission of fluorophores on the nanowire surface, which led to an enhanced signal at nanowires' tip. (d-f) Epifluorescence images in topview can be viewed of (d) a GaP nanowire substrate, (e) a silicon substrate, and (f) a MaxiSorp black polymer substrate, dotted with antibodies. The biotinylated serum concentration was diluted to $0.4 \%$ (which was the highest concentration used in this application). Individual nanowires can be seen in (d) as bright spots. The edge of the scFv spot is shown in (e,f), which shows the change in signal between specific and unspecific binding to the antibodies. Reproduced from Reference [27] with permission 
p-BNC card by inserting a sample, which went through the sample loop and took advantage of the waste chamber to ensure a fixed amount of the sample to enter only [31]. Next, a pump adapter passed buffer into the channel which moved the sample to the bead-holding chip through to the waste; the second pump then passed detecting antibodies from the glass pad into the chip [31]. The increased rate of the flow in the second pump allowed for the removal of unbound reagents and the final washing step [31]. The pumped fluid moved into the bubble trap, which removed bubbles and included a filter to take out debris [31]. Finally, imaging was done using an epifluorescence microscope. The LODs for the four protein markers CA125, HE4, MMP-7, and CA72-4 were $1.8 \mathrm{U} / \mathrm{mL}$, $2.3 \mathrm{pmol} / \mathrm{L}, 0.2 \mathrm{ng} / \mathrm{mL}$, and $1.7 \mathrm{U} / \mathrm{mL}$, comparable or superior than those from conventional ELISA [32]. High sensitivity, multiplexity, lower costs, and high specificity made this method promising for early cancer detection. Further miniaturization of the agarose beads could result in higher assay sensitivity and lower sample consumption. Exploration of the storage conditions of the assay reagents would made it suitable for potential clinical tests [31].

Microwell-based approach relies on micro-fabrication methods to develop distinctively sized wells for highthroughput protein assays on a chip [33]. Spatial arrangement of single cells has been realized with the microwell chip to reduce cell-to-cell variation noise and study the heterogeneity between cell populations [34]. Choi et al. used an immunohybridized chain (HCR) reaction to enhance the detection of secreted cytokines and chemokines from human mononuclear cells. Sandwich immunoassays were performed on the microwell chip made from silicone elastomer consisting of $72 \times 24$ blocks that contained a $7 \times 7$ array of microwells (50 $\mu \mathrm{m}$ for all the three dimensions) adhered to a glass slide [35]. The immuno-HCR used oligo-nucleotide-based initiators covalently linked to antibodies which caused a chain reaction of hybridization events with a pair of complementary hairpin oligomers bearing fluorescent labels. By integrating this method with micro-engraving techniques, which is a soft lithographic method for printing arrays of secreted proteins from thousands of single cells, the assay sensitivity was improved. The lower LOD achieved was $10-20 \mathrm{pg} / \mathrm{mL}$ for human IL-9 [35]. This method can be easily integrated with standard protocols for processing microarrays, and has achieved low LOD that allowed for single cell protein analysis. However, the number of the fluorophores associated with a certain protein may differ in a nonlinear manner, which means that the degree of polymerization of the HCR products may vary from assay to assay [35]. More tests could be performed to demonstrate the inter-assay reproducibility.

Another well-developed example of highly sensitive microwell-based protein assay is digital ELISA (dELISA). Recently, dELISA has been used for proteomic studies because of its high sensitivity, accuracy, and throughput [36, 37]. Importantly, dELISA has allowed for protein analysis with detection limits at levels that could not be reached by conventional ELISA. For example, Rissin et al. developed a single-molecule dELISA consisting of antibody-coated micro-beads $(2.7 \mu \mathrm{m}$ diameter) for specific protein capture, a microwell $(4.5 \mu \mathrm{m}$ diameter and $3.25 \mu \mathrm{m}$ depth) array for holding one bead per microwell, and fluorescence detection at a single-molecule level [38]. Specifically, arrays of femtoliter-sized reaction chambers, termed single-molecule arrays (SiMoAs), were made to isolate and detect single-enzyme molecules. The molecules were captured and fluorescently labelled on antibody-coated microbeads using standard ELISA reagents [38]. The beads were then loaded into the femtoliter-volume well arrays for the detection of single molecules by fluorescence imaging (see Fig. 2). SiMoAs enabled detection of low concentrations of enzymes by its confinement of the reporter fluorophores in the extremely small volumes for signal enrichment, which ensured a high local concentration of the fluorophores. In this case, the loading of the beads into the array of femtoliter-sized wells (2-mm-wide arrays with $\sim 50,000$ wells) was used to achieve this confinement [38]. Time-lapsed fluorescence images of the array using standard microscope optics were taken to distinguish beads with or without the captured enzyme molecule; therefore, the assay readout was digital (either 0 or 1) [38]. This approach allowed for low background noise and a low LOD of $\sim 50$ aM of the prostatespecific antigens being detected within $2 \mathrm{~h}$ [38].

A droplet microfluidics-based dELISA platform was innovated by Yelleswarapu et al. that could operate 100 -fold faster than a single droplet generator, by using the parallel integration and operation of hundred droplet generators onto a single chip [39]. This platform consisted of a microbead processor, a droplet generator, and a microfluidic channel. A mobile phone-based detector was used to detect the droplets' fluorescence [39]. Specifically, a microbead processor was used for the

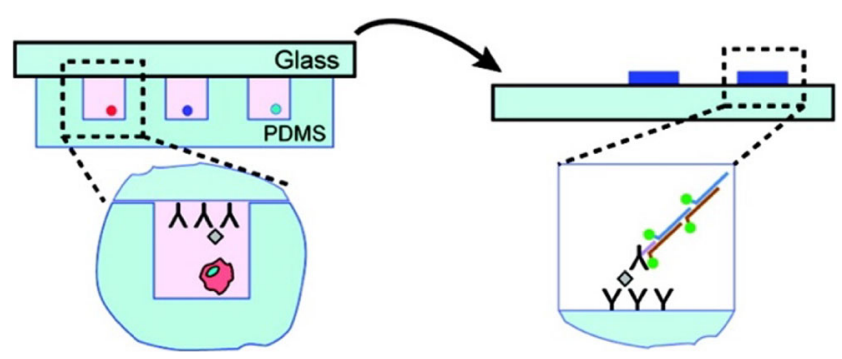

Fig. 2 Schematic for application of immuno-HCR after micro-engraving to allow for the detection of proteins secreted from single cells. Cells were deposited into microwells at a density of $\sim 1$ cell/well, and sealed with a glass slide containing a mixture of capture antibodies. After incubation, the glass was removed, and the signal was amplified relative to each capture event used from the immuno-HCR. Reproduced from Reference [38] with permission 
microbeads $(d=5.4 \mu \mathrm{m})$ to capture their target proteins from serum. The beads were then tagged with enzymelabeled immunocomplexes for downstream amplification within droplets $(d=40 \mu \mathrm{m})$ and got washed between each labeling step. A droplet generator was used to mix the microbeads with the enzyme's substrate and encapsulate into water-in-oil droplets. A 3D microfluidic channel was implemented to allow for the droplets to pass, providing time for the enzymatic amplification of the fluorescence signal [39]. By using the fluorescence color-coded microbead processing unit, the system was able to reach a LOD of $300 \mathrm{aM}$ for the endogenous GM-CSF and IL6 proteins in human serum, which was 1000-fold lower than that of conventional ELISA thanks to the assay miniaturization on microbeads and the high molecular binding capacity of the microbeads allowing more target proteins to be enriched [39]. This system provided a high sensitivity, matched the LOD to existing dELISA technologies, and required fewer steps. However, it took a longer time to process the samples and the micro-fabrication procedures for the device fabrication.

A further development of the dELISA technology was done by Akama et al., which used a tyramide signal amplification system to concentrate the enzyme reactions instead of using droplets [40]. In conventional dELISA, droplets are used for signal amplification to detect signals from a single target molecule, which would require complex methods to produce multiple same-sized microdroplets with relatively high costs [40]. Therefore, a droplet-free system can be beneficial to simplify the process (Fig. 3). In this particular system, the protein molecules were captured by beads and labelled with horseradish peroxidase (HRP). The tyramide substrates then reacted with HRP and turned into radical intermediates, which settled on the beads. To perform this, capture antibodies were immobilized on magnetic beads, then the beads were dispersed in $1 \%$ BSA blocking buffer and incubated [40]. The beads were washed and sequentially dispersed in various concentrations of hepatitis B surface antigen (HBsAg) solution ( $75 \mu \mathrm{L})$, a solution of biotinylated detection antibody, and streptavidin-labeled HRP (50 $\mathrm{pM})$. This process allowed for a single target molecule and enzyme complex on the same bead. Using flow cytometry, the beads were digitally counted, and the fluorescence signals were measured. The LOD for hepatitis B reached $139 \mathrm{aM}$, over 20 -fold more sensitive than that of conventional ELISA, with a reaction time of 30 min [40]. This method allowed for high assay sensitivity and the elimination of sophisticated equipment; however, it required multiple repetitive steps involving mixing, washing, and separating reagents which can be tedious and inconvenient for experimenters (Fig. 3).
Improving the binding capacity of the capture antibodies

Conventional immunoassays such as ELISA rely on a 2D surface as the reaction platform, with limited antibody binding capacity. Strategies have been developed to increase the binding capacities of the capture antibodies by using engineered particles and platforms [41], so that more analyte protein molecules can be captured and enriched from samples, thus achieving high assay sensitivity.

\section{Via using micro- and nanoparticles as the reaction surface}

Micro- and nanoparticles have larger surface-to-volume ratios compared to bulk materials, allowing more capture probes to be used for extracting target proteins from sample solutions, thus improving the assay sensitivity. For example, a beadbased immunoassay was developed by Huergo et al. taking advantage of magnetic nanoparticles to detect human SARS$\mathrm{CoV}-2$ antibodies [42]. First, these MagneHis $\mathrm{Ni}^{2+}$ magnetic beads were washed twice with Tris-buffered saline with $0.1 \%$ Tween ${ }^{\circledR} 20$ Detergent (TBST) and resuspended to incubate with purified His-tagged SARS-CoV-2 nucleocapsid N protein. Following washing steps and aliquoting in 96-well plates, diluted human serum from COVID-19-positive and control subjects was added directly to the wells and incubated for $2 \mathrm{~min}$. The magnetic beads and the serum were allowed to mix. Using a magnetic extractor device, the beads were captured and washed. The beads were then incubated with goat anti-human IgG-HPR and washed again. The total procedure time was determined to be less than $12 \mathrm{~min}$, with only $2 \mu \mathrm{L}$ of serum needed (10 times lower than ELISA), due to the high assay sensitivity derived from the high molecular binding capacity of nanoparticles. The results were shown by color, as the negative controls were blank, but the COVID-19-positive samples showed a strong blue color indicating the presence of IgG reacting with the SARS-CoV-2 N protein. Comparing this system to classic ELISA, the magnetic system showed sensitivity of $97 \%$ and $100 \%$ specificity, whereas classic ELISA performed at $90 \%$ sensitivity and $100 \%$ specificity. High sensitivity, low quantities of reagents and plasma required, and short assay time are advantages of this system; however, access to magnetic nanoparticles is required for this application.

Lee et al. developed a multiplexed immunoassay using hydrogel microparticles [43]. Porous gel-based microparticles allowed for high antibody binding capacity thus improving the assay sensitivity. For the synthesis of antibody functionalized hydrogel particles, PEG-linked antibodies were mixed with a prepolymer solution containing PEGDA700, PEG200, photo-initiator, and Tris-EDTA. The mixture was introduced into a microfluidic chip and exposed to UV lights 
a) Immunoassay

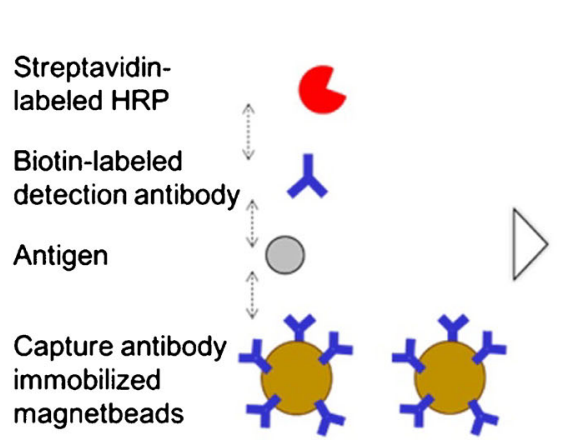

Fig. 3 Droplet-free digital ELISA based on tyramide signal amplification system illustration. (a) Capture of single-protein molecules on beads and labelling with HRP. (b) Reaction of biotinylated tyramides with HRP and conversion into tyramide radicals to deposit onto the beads with labeled

\section{c) Fluorescent labeling}

Biotin-labeled

tyramide

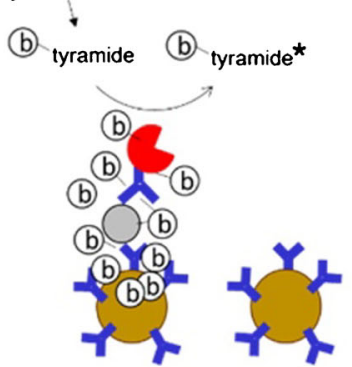

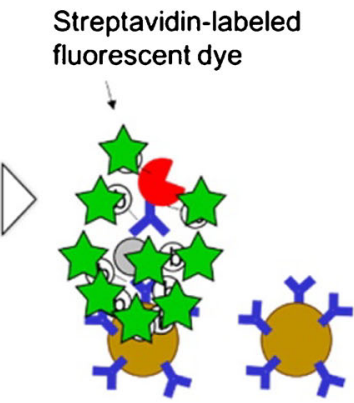

d) Detection by FCM

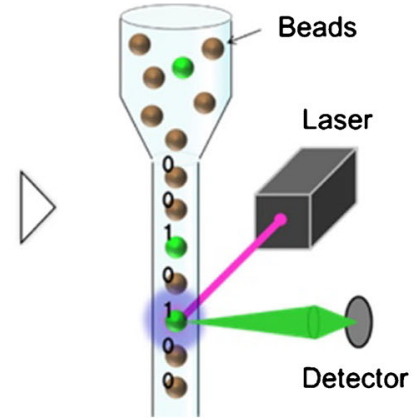

HRP. (c) Binding of streptavidin-labeled fluorescent dyes to biotin on the beads. (d) Digital counting of the beads by flow cytometry. Reproduced from reference [40] with permission

for particle synthesis. As for the immunoassay, antibodyfunctionalized microparticles were mixed with sample solutions, and then $10 \mu \mathrm{L}$ of the reconstituted secondary antibody was added. These secondary antibodies were labeled fluorescently with streptavidin-phycoerythrin. After washing steps, using an inverted fluorescence microscope with a $\lambda_{\mathrm{es}} / \lambda_{\mathrm{em}}$ of $546 / 590 \mathrm{~nm}$, images were taken and analyzed. This method was able to detect VEGF from $17.7 \mathrm{pg} / \mathrm{mL}$ up to $60,000 \mathrm{pg} /$ $\mathrm{mL}$, a much wider dynamic range compared to $31.2-2000 \mathrm{pg} /$ $\mathrm{mL}$ for ELISA.

Snider et al. developed a microbead-based assay for quantification of proteins [44]. This assay, referred to as FRANC (Flexible, Robust Assay for quantification and Normalization of target protein Concentration) was used for detecting recombinant TNF-alpha and IL-1 $\beta$. This system consisted of four steps: firstly, the protein sample was attached to magnetic hydrophobic microbeads (diameter $=1.05 \mu \mathrm{m}$ ) by incubation, followed by microbead removal from solution by using a neodymium bar magnet $(0.75$ in. length $\times 0.25$ in. width $\times$ $0.25 \mathrm{in}$. height, $10.5 \mathrm{lbs}$ pull force). After resuspension, the beads were added to protein sample and incubated. They were magnetically removed again by a 96-well magnetic plate separator (96.25 in. diameter $\times 0.25$ in. thick cylindrical magnets assembled in a 96-well plate). The beads were then washed and incubated with the antibody solution, using standard fluorophoreconjugated antibodies. To detect all the proteins in sample, EDC and NHS were added, agitated, and washed; fluorescein dye was added to the solution. Lastly, beadbased flow cytometry was used to read fluorescent signals from the proteins and total proteins (Fig. 4). The limit of detection of this platform was determined to be $60 \mathrm{pg}$ for TNF- $\alpha$ protein (range of $60 \mathrm{pg}-12.5 \mathrm{ng}$ ), while the recombinant IL-1 $\beta$ was detected with a limit of detection of $70 \mathrm{fg}$ (range of $70 \mathrm{fg}-34 \mathrm{pg}$ ).
In addition, Lin et al. developed a semiconductor sensor with magnetic beads to conduct protein detection on the urinary protein apolipoprotein A1. The 120-nm magnetic beads were used to create an immunoassay for protein isolation [45]. First, to isolate the proteins from the sample, a magnetic beadbased immunoassay was performed with the antibodyconjugated beads. Next, in order to increase the electric charge of the antigen-antibody complex, negatively charged DNA fragments were used as the secondary antibody label. Finally, an external magnetic field was applied to adsorb the antigen-antibody complex to a semiconductor sensor surface. This way the charged complex at the bottom of the magnetic beads was forced to make contact with the sensor surface. By using longer DNA fragments as secondary labels, the generated signal was 15 times greater than that without the labels, and the platform was able to reach a LOD of $12.5 \mathrm{ng} / \mathrm{mL}$ [45]. This method allowed for a low LOD and a portable device size, however requiring equipment for the fabrication of the semiconductor sensor.

\section{Via engineering biochips}

To increase the antibody binding capacity, some methods have involved engineering traditional immunoassay platforms, as well as integrating 3D nanopatterns, hydrogels, and cellulose membranes to improve protein detection sensitivity via increasing the antibody binding capacity.

For example, Li et al. created a carbon nanotube (CNT) nano-sensor for protein analysis [46]. To increase sensitivity, this device included a gold electrode surface with CNTs for crossing the electrodes [46]. This allowed for performing electrophoresis and CNT tunnel conductance. Specifically, after target proteins were introduced to bind with the capture antibodies on the gold electrodes that were $1 \mu \mathrm{m}$ separated from each other, a solution containing the detection antibody-functionalized 
Fig. 4 Schematic of the FRANC assay process: (A) protein samples. (B) The protein samples were biotinylated. (C) The samples were then conjugated to magnetic microbeads by biotinstreptavidin interactions. (D) Microbeads were then exposed to fluorescently labelled antibodies to tag the proteins of interest. (E) They were then fluorescently labeled to find out the total protein amount, which was required for normalization against protein amount. (F-H) Microbeads were analyzed by flow cytometry. (F) Forward vs. side scatter plots were utilized to differentiate between singlet microbeads and aggregates. (G) Antibody detection for each sample-conjugated microbead set is shown. $(\mathrm{H})$ Total protein signal detection is shown for each sample-conjugated microbead set. Reproduced from reference [44] with permission
A

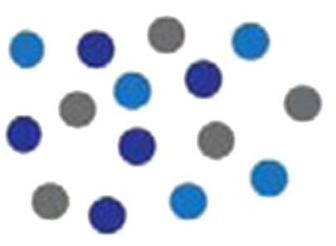

B

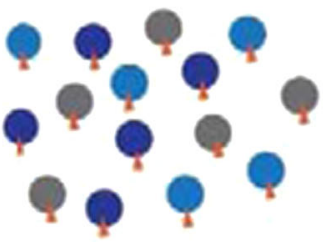

C
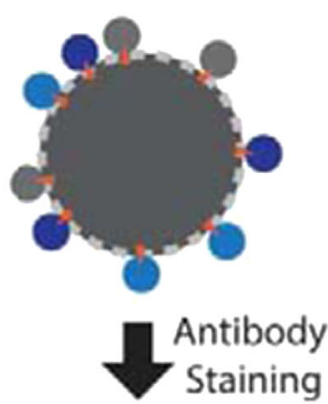

D

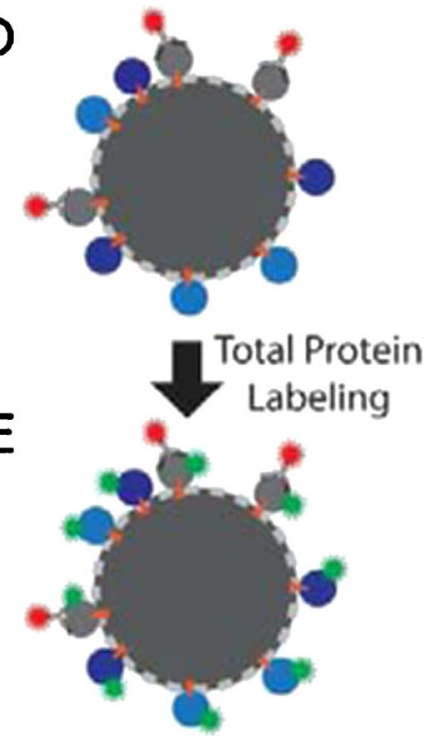

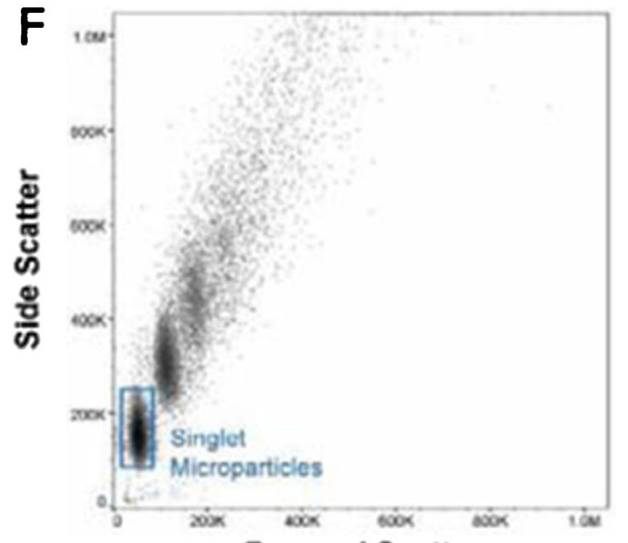

G
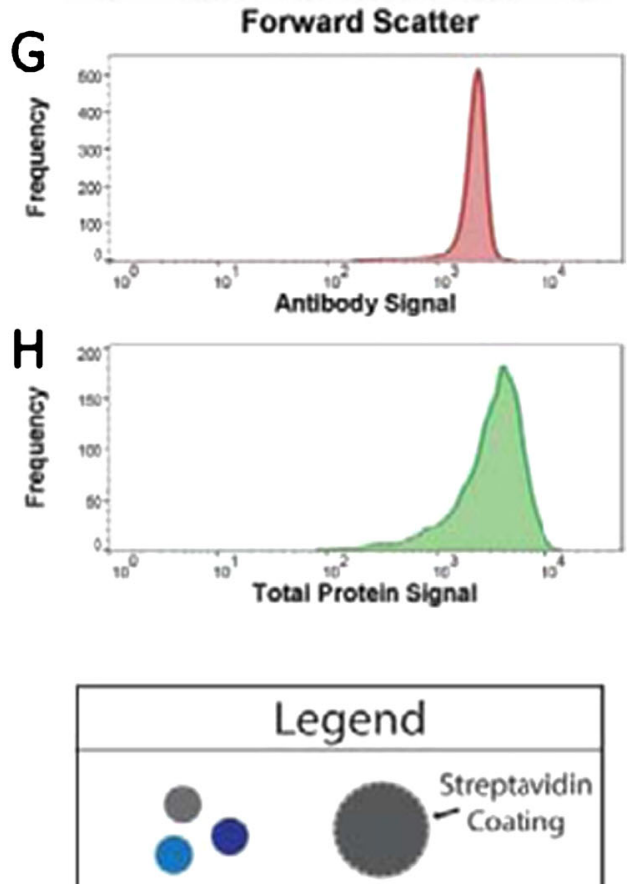

Proteins

Microbeads
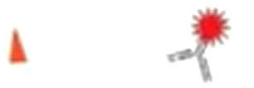

Biotin

Fluorescent

Total Protein Antibody
CNTs was introduced by electrophoresis to form the antibody-antigen-antibody complexes. Then, a crossflow was passed across the assembled CNTs to remove the non-target CNT complexes. By using the protein HER2 as a target, this platform was able to achieve a detection limit of lower than $100 \mathrm{fM}$ by measuring the electrical current signals [46].
Zhang et al. developed a 3D nanopattern microfluidic chip for ultrasensitive protein detection [47]. This method used a $3 \mathrm{D}$ herringbone nanopattern to promote mass transfer, increase surface area, and improve probe density for improved assay sensitivity [47]. To overcome the complications with surface reaction and boundary effects, this method used a multiscale integration by designed self-assembly (MINDS) 
which exploited micro fluidically engineered colloidal selfassembly (CSA) to create the nanostructure and patterns [47]. This platform, integrated with ELISA assay format, was used to analyze proteins on tumor-derived exosomes [47]. When calibrated for protein immunoassay, the device achieved a LOD of $10 \mathrm{fg} / \mathrm{mL}$ for both proteins EpCAM and FR $\alpha$, superior than conventional ELISA [47]. However, the 3D herringbone nanopattern required nanofabrication techniques, not widely available for most biological labs, limiting its wide application.

Li et al. created a 3D hydrogel droplet antibody microarray that entrapped antibody-coated microbeads in hydrogel droplets for protein quantification [48]. Microbeads with $1-\mu \mathrm{m}$ diameter were coated with capture antibodies and were further captured within alginate hydrogel droplet arrays [48]. To investigate its application, this platform was used for a multiplex sandwich immunoassay analyzing proteins [48]. Specifically, alginate solutions were first mixed with antibody-coated beads and spotted on a slide using an inkjet spotter. After the spotting step, the slides were soaked in calcium solution to form alginate gels, which formed the 3D hydrogel structures. The slide was then incubated with sample solution, followed by the detection antibody labelled with biotin and then streptavidin-Cy5. After drying, a fluorescence image of the slide was acquired using a microarray scanner. This platform was used for multiplexed sandwich immunoassays to detect 6 proteins including cytokines and candidate breast cancer biomarkers in serum. A LOD lower than $100 \mathrm{pg} / \mathrm{mL}$, with the lowest reaching $5 \mathrm{pg} / \mathrm{mL}$ with $1 \mathrm{~h}$ of incubation, was reached [48]. This method showed advantages such as multiplexing, low-cost, and high sensitivity. However, the hydrogel droplets were relatively soft and fragile due to a high water content, thus needing to be handled with care during the assay procedure.

A similar platform based on the beads-in-hydrogel technique was made by Jang et al. where metal-enhanced fluorescence hydrogel microarrays were used to trap silica-coated $(17.5 \mathrm{~nm})$ silver NPs (AgNPs) [49]. Within the microfluid channels, UV light was used for the hydrogel gelation, forming the gel structure of $100 \mu \mathrm{m}$ in diameter and $40 \mu \mathrm{m}$ in height to encapsulate NPs for immunoassays [49]. For a proof of concept, this platform increased the LOD for glucose detection to $0.05 \mu \mathrm{M}$ and could be potentially used for highly sensitive protein analysis [49].

Another method was developed by Shen et al., where a centrifugation-assisted lateral flow immunoassay (CLFIA) was proposed to enhance sensitivity compared to traditional LFIA [50]. A piece of nitrocellulose membrane with a test and a control line was inserted into a centrifugal disc. The antibody was gold nanoparticle (AuNP, with a radius of $20 \mathrm{~nm}$ ) labelled, which was lyophilized and preloaded into the disc. The sample volume on the disc was not limited as it was powered by centrifugal force, and the flow rate of the reaction fluid was kept stable and adaptable to different speeds. To control the CFLIA on the disc, a portable device was made to rotate the disc with a stepper motor and receive the results using a smartphone. Using human prostate specific-antigen (PSA) as the target, the detection limit for this platform was found to be $0.067 \mathrm{ng} / \mathrm{mL}$, an improvement of 6.2 -fold compared to traditional LFIA, enabled by both the centrifugationassisted liquid transfer method and the use of gold nanoparticles as signal reporters. This method is highly sensitive, portable, and adjustable, but it does require manufacturing of devices to rotate disc.

To further enhance the membrane-based method, SenaTorralba et al. printed wax barriers on top of the nitrocellulose membrane [51]. This was done to slow down fluid flow at the bio-recognition line for an increase in the antibody-antigen binding to improve the assay sensitivity [51]. Conjugated gold nanoparticles $(\sim 17 \mathrm{~nm})$ were also used for signal enhancement within the lateral flow assay [51]. This platform tested different barrier widths and found $0.05 \mathrm{~mm}$ to be the optimal size, which was able to reach a LOD of $14 \mathrm{ng} / \mathrm{mL}$ for detecting human IgGs and an incubation time of $12 \mathrm{~min}$, making this 52-fold more sensitive compared to conventional lateral flow assays (LFA) [51].

\section{Sample purification via LOC}

The sensitivity of protein assays can be improved through sample purification, by which background noise is reduced, improving the signal-to-noise ratio in turn. Traditionally, a bio-fluid separation has been performed by centrifugation or chromatography. Recently, there has been technological development integrated with LOC systems, such as microscaleelectrophoresis, microfiltration, micropillars, and magnetic microbeads to perform purification to increase detection sensitivity [52]. Examples of the biofluids for such applications include whole blood and its derivatives plasma and serum. Due to the varying characteristics such as size, density, and shape of the different constituent elements in whole blood, blood cells and plasma can be separated by a multitude of ways before protein analysis [53].

Qin et al. were able to develop a self-powered microfluidic chip that allowed for multiplexed protein assays from whole blood [54]. Whole blood was introduced through a microchamber, and went through 6 skimming channels (each $10 \mu \mathrm{m}$ in diameter) with different widths, which separated the blood into plasma. The separation was based on different flow rates of the blood components. This blood separation system was combined with an Integrated Blood Barcode Chip (IBBC) designed for multiplexed protein marker detection [54]. The bottom glass surfaces of the plasma channels were prepatterned with ssDNA barcodes. These barcodes got converted into antibody barcodes using the DNA-encoded antibody 
libraries. Following separation, plasma protein markers were captured onto individual barcode strips via specific antibodyantigen binding. Each strip in a barcode represented an assay for one protein, and a complete barcode represented a full assay for a panel of 12 protein markers. The sandwich assay was completed by flowing biotinylated antibodies, followed by fluorescently labeled streptavidin. After rinsing and drying, the barcode slides were read using a standard microarray scanner, with the detected proteins appearing as fluorescent bars. In a typical assay, a finger prick of human blood $(2 \mu \mathrm{L})$ was taken and applied by a syringe to the sample reservoir, where it was mixed with $20 \mu \mathrm{L}$ of a preloaded EDTA/BSA/PBS solution by diffusion before applying onto the chip (Fig. 5). Using this method, the IL-12 protein concentration was detected with a LOD of approximately $0.4 \mathrm{pM}$ [54]. Since this method was fully automated and requires a few steps, it can be used in remote locations by minimally trained staff to reach a good sensitivity. However, DNA barcodes and DNA-encoded antibodies were required, limiting its wide application.

In addition, integrated lab-on-disc platforms have been developed for whole biofluid filtration, processing, and protein analysis by on-disc ELISA [55, 56]. Lee et al. designed a labon-disc platform that was able to process whole blood samples, and perform a plasma separation by integrating microvalves and centrifugal microfluidics before protein analysis [55]. This device took advantage of a laser-irradiated ferrowax microvalve (LFIM), based on transitioning of phase in ferrowax, which was paraffin wax embedded with iron oxide nanoparticles $(10 \mathrm{~nm})$ [55]. In this lab-on-disc method, first the blood was applied to reagent preloaded disc $(d=12$ $\mathrm{cm})$. Microfluidic channels in the bottom plate were used to transfer liquids between reservoirs. The width of the channel was $1 \mathrm{~mm}$ and the depth was $100 \mu \mathrm{m}$. The top plate had holes for sample injection or air vent. The two pieces were bonded by a UV curing glue [55]. After inserting the sample, plasma was separated by spinning the disc at $3600 \mathrm{rpm}$ for $3 \mathrm{~min}$. By opening a valve, plasma got transferred to the metering chambers and filled each chamber. Next, the second valve was opened to transfer the excess amount of plasma to the excess plasma chamber. The third and fourth valves were then opened to transfer the $150 \mu \mathrm{L}$ of the secondary antibody modified with horseradish peroxidase (HRP) and the metered plas$\mathrm{ma}(50 \mu \mathrm{L})$ to the mixing chamber in the immunoassay side. Each metered plasma was then transferred to the plasma dilution chamber by repeating the sequential illumination of the laser light on the fifth and sixth valves. The metered plasma was then diluted with preloaded buffer, and mixed by repeating the rotation of the disc clockwise and counter-clockwise. Meanwhile, the target analytes were captured on silica beads $(d=1 \mathrm{~mm})$, which were preloaded to the mixing chamber. After incubation for $9 \mathrm{~min}$, the plasma residue was removed by operating the other two valves. Finally, the washing buffer was released. The diluted plasma filled the detection cuvettes preloaded with lyophilized reagents by opening the next two valves. During this step, lyophilized reagents were dissolved in the serum and the absorbances were measured by a built-in spectrophotometer [55]. The substrate, tetramethyl benzidine (TMB) in dimethyl sulfoxide (DMSO) was transferred to the mixing chamber and incubated for $6 \mathrm{~min}$. Finally, the stopping solution $\left(\mathrm{H}_{2} \mathrm{SO}_{4}\right)$ was transferred to the mixing chamber and
Fig. 5 Strategy for the detection of proteins using wax barriers on top of a nitrocellulose membrane. (A) Schematic of different pads present in the LFA strip. (B) In the standard LFA, the flow constantly moved to the absorbent pad and the bio-recognition event occurred within seconds. Few labelled antibodies were captured in the test line (TL); therefore, the signal intensity was weak. (C) In the LFA modified with a wax barrier, the flow was temporarily stopped on the TL, resulting in increased time for the biorecognition event. (D) Fluorescence microscope pictures $(40 \times)$ of the wax barrier on the LFA strip. The wax barrier temporarily held the solution for 12 min. Reproduced with permission from reference [54]

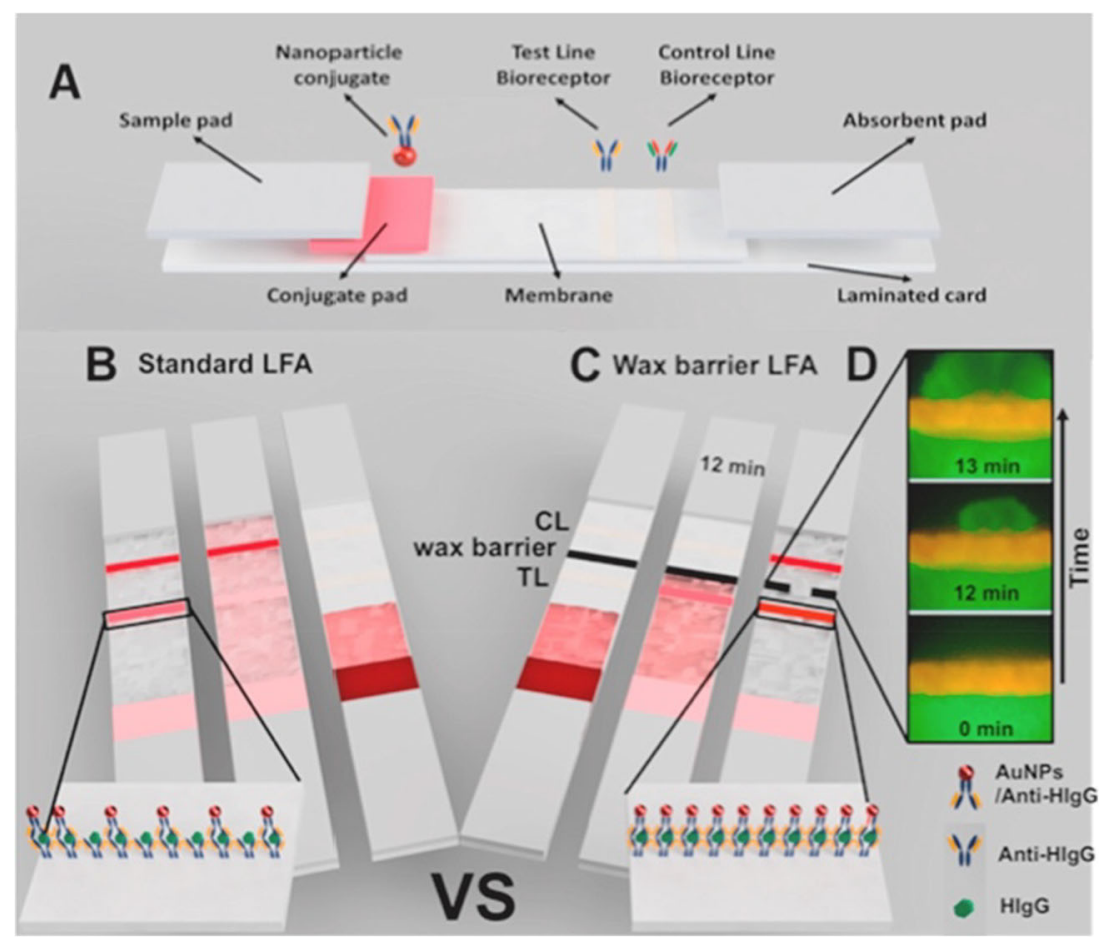


then transferred to the detection chamber. The device achieved dynamic range of $0.92-100 \mathrm{ng} / \mathrm{mL}$ and a LOD of $0.70 \mathrm{ng} / \mathrm{mL}$ within 22 min for six biochemical analytes: total cholesterol (CHOL), high-density lipoprotein cholesterol (HDL), triglycerides (TRIG), alanine aminotransferase (ALT), aspartate aminotransferase (AST), and glucose (GLU), and CK-MB (muscle and brain fraction of creatine kinase) [55]. This method had a high sensitivity, could analyze whole blood in a short period of time, required a very small sample volume, and can be potentially used for point-of-care applications. It might be worthwhile to explore multiplexed protein measurement as a future direction.

\section{Signal amplification techniques}

\section{Via using novel signal reporters}

With the integration of novel signal reporters such as quantum dots (QDs), nanoparticles, and nucleic acids, the signals of the protein assays can be amplified, either by the nanomaterials themselves (e.g., with QDs) or by PCR procedures (e.g., using nucleic acids as signal reporters), thus stronger than those from conventional reporters, in turn improving the protein assay sensitivity [29, 57, 58].

Quantum dots exhibit a photostable luminescence signal, and when used for protein detection offer a great visual of molecule detection [59]. Typically, these particles are modified for targeting specific proteins and generating stronger signals than conventional reporters, which can improve the LODs [59]. In a study, fluorescence magnetic microbeads $(13.5 \mu \mathrm{m})$ were created by integrating the encoding of quantum dots onto the microbeads, and used on a microfluidic chip for protein detection [60]. A sandwich immunoassay was carried out by mixing the fluorescence-encoded antibody-coated magnetic microbeads with the sample containing proteins. After $2 \mathrm{~h}$, magnetic enrichment and separation were done to remove the unbound analytes. After washing, the microbeads were dispersed in PBS buffer. Then, the QDs conjugated with a secondary antibody were introduced and incubated in a shaker for $2 \mathrm{~h}$. Finally, photoluminescence (PL) spectra were measured using a spectrophotometer [59]. The system was used to target the protein AFP, and a measurable signal was generated with an LOD of $0.60 \mathrm{ng} / \mathrm{mL}$ [60]. This work showed promise in achieving a high sensitivity with relatively simple assay procedure; however, encoding of the QDs onto magnetic beads and antibodies was required. Multiplexed assays could be achieved by re-engineering of the microfluidic chip configuration.

Tang et al. produced a method to detect biomarkers for Alzheimer's disease using QDs [61]. Using a sandwich immunoassay approach, the QDs were used as fluorescent labels to detect amyloid-beta peptide $1-42\left(\mathrm{~A} \beta_{1-42}\right)$. C-Terminal antibody $(\mathrm{C}-\mathrm{Ab})$, and biotinylated $\mathrm{N}$-terminal antibody $(\mathrm{N}-$ $\mathrm{Ab})$ were able to specifically bind to the $A \beta_{1-42}$ and make sandwich immunocomplexes; the streptavidin-modified QDs would then attach to biotinylated N-Ab. By detecting the fluorescence intensity of the supernatant, the concentration of $A \beta_{1-42}$ could be found (Fig. 6). This method showed an LOD of $1.7 \mathrm{pM}$, with a reaction time of $6 \mathrm{~h}$, and was implemented in cerebrospinal fluid. The low LOD and ease of process make this a promising platform for clinical applications.

In addition, nucleic acids have been used as a type of amplifiable signal reporter. Proximity ligation assay (PLA) is an immunoassay technique using DNA ligation that can amplify signals via PCR for highly selective and sensitive protein detection $[62,63]$. Castro-López et al. created a microfluidic device using both magnetic beads and PLA for on-chip protein analysis [64]. The magnetic beads were coated with antibody conjugate. An oligonucleotide was integrated with both primary and secondary antibodies to promote ligation when the antigen was in proximity, followed by amplifying the ligated product with a polymer chain reaction (PCR) [64]. The assay developed in this device used a PLA in which one of the assay proximity probes was directly immobilized onto the magnetic beads. The device was based on a disposable and single-use cyclo-olefin polymer (COP) microfluidic chip integrated with a quantitative real-time polymerase chain reaction (qPCR) device. Sample volume was $10 \mu \mathrm{L}$ and total assay time was under $3 \mathrm{~h}$. The device offered portability, small reagent and sample consumption, and fast time-to-results compared with standard ELISAs. It achieved a LOD of 3.1 $\mathrm{pg} / \mathrm{mL}$ when analyzing the protein TNF- $\alpha$ [64]. In addition to sensitivity, the assay specificity could also be improved due to the specific DNA ligation process. However, multiple steps in manufacturing and the operation were required.

Similarly, Darmanis et al. used a solid-phase PLA with magnetic microparticle for protein detection. Antibody was immobilized on magnetic beads, then a PLA was performed for protein detection and signal amplification [65]. Notably, this microparticle-based solid-phase PLA depended on the recognition of target proteins by three antibody molecules. After being captured by a microparticle, solid-phase pairs of the proximity probes were added (Fig. 7). This technique was compared to standard sandwich ELISA and this technology showed a $\sim 100$ times lower concentration needed for detection [65]. The detection of the protein VEGF in plasma samples reached a LOD of $5.2 \mathrm{fM}$ [65]. This technique was highly sensitive, but the use of three antibodies increased the assay cost and the time for antibody selection. Also, if multiple proteins are to be detected, the cost would be relatively high.

\section{Surface enhancement techniques}

When analyzing proteins at low concentration levels, the signals generated from the platform can be small due to the low 
Fig. 6 A schematic diagram for the $\mathrm{A} \beta_{1-42}$ sandwich assay using double antibody. Reproduced from reference [61] with permission

\section{Binding C-Ab inside the 96- well plate; blocking with free- protein buffer; washing.}

2. Adding $\mathbf{A}_{1,12}$; washing.

\section{Adding Biotinylated N-Ab;} washing.

\section{Adding Streptavidin-QDs; washing.}
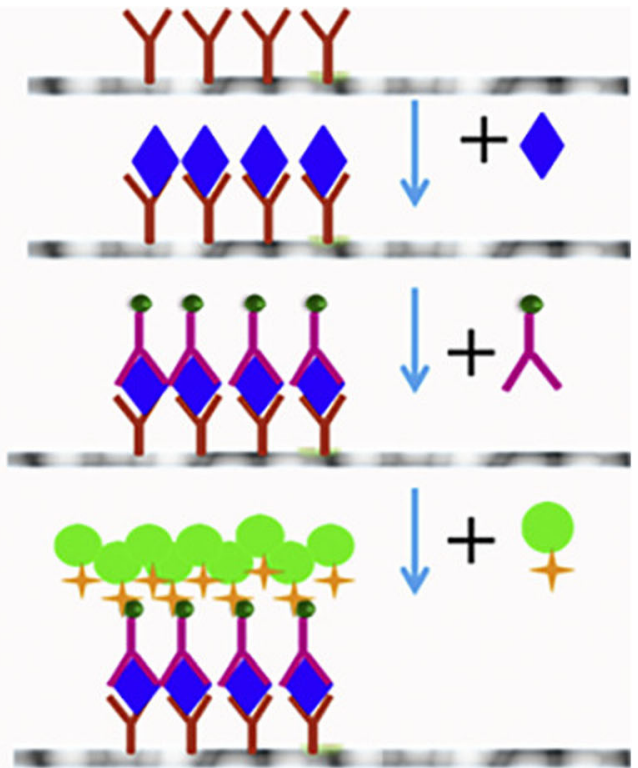

\section{Fluorescence detection.}

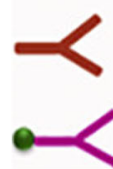

$\mathbf{C - A b}$

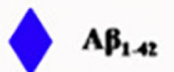

Biotinylated N-Ab

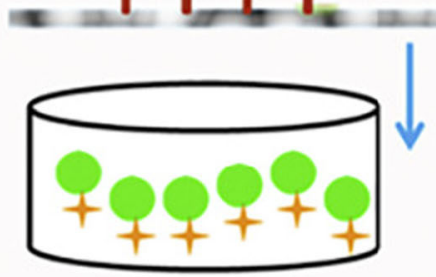

Streptavidin-QDs amount of the specific protein target. To overcome this, surface modifications with materials such as gold and nanoparticles can increase sensing capabilities via surface plasmonenhanced detection. This strategy can be used for both labelbased and non-labeled-based signal detection, as discussed below.

Min et al. investigated a surface plasmon-enhanced method for multiplexed characterization of extracellular vesicles (EVs) to amplify the fluorescence signals using plasmon resonances excited by periodic gold nanohole structures [66].
More specifically, the EVs were first captured on Au nanohole surface by affinity ligands and then fluorescently labelled antibodies with different colors were used for immunostaining. In this platform, the hole diameter was $200 \mathrm{~nm}$ and the periodicity was $500 \mathrm{~nm}$ in a 100 -nm-thick $\mathrm{Au}$ film. The periodic nanohole grating on the chip surface was able to concentrate the electromagnetic fields with a maximum intensity of 300fold. The resonance field mostly covered small EVS (average diameter of $100 \mathrm{~nm}$ ), as it extended to $110 \mathrm{~nm}$ in the $\mathrm{z}$-direction. Using this method, both membrane and intra-vesicular

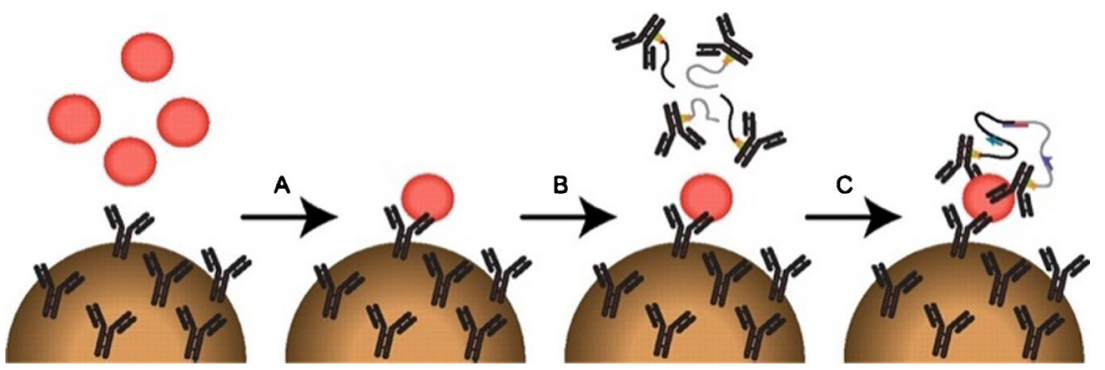

Fig. 7 A schematic of the solid-phase PLA protocol (SP-PLA). (A) The samples were incubated with pre-immobilized antibodies on microparticles. (B) The microparticles were washed and incubated with pairs of PLA probes. (C) Upon binding of an antigen and adding connector

oligonucleotides, the oligonucleotides on the PLA probes were ligated. This process was followed by enhancement and detection of the ligated products by PCR, with the primers shown in arrows. Reproduced from reference [65] with permission 
protein markers could be identified at the single EV level, and an amplification of one order of magnitude could be shown for fluorescence signals in multiple channels.

Mai et al. used disposable fiber optic biosensors for two kinds of immunoassays [67]. These biosensors were based on surface plasmon resonance (SPR) by surface decoration with half-antibody fragments. Firstly, these SRP biosensors were fabricated from a sandwiched gold film-coated single-mode fiber $(9-\mu \mathrm{m}$ core and $125-\mu \mathrm{m}$ cladding diameters) by two multimode fibers $(62.5-\mu \mathrm{m}$ core and $125-\mu \mathrm{m}$ cladding diameters). For the first immunoassay, the biosensors were decorated with fragments of half-antibody, using mouse IgG (M$\mathrm{IgG})$ and goat anti-mouse $\operatorname{IgG}(\mathrm{GAM}-\mathrm{IgG})$ as the antigen and antibody, respectively. The other immunoassay involved an antigen-decorated probe with an LOD of $0.1 \mu \mathrm{g} / \mathrm{mL}$, which is improved 10 times compared to the antibody-decorated fiber probe. This method has advantages such as high sensitivity, simplicity, miniaturization, and low cost, but requires access to fragments of half antibodies.

De La Rica et al. made an interesting approach by using a plasmonic ELISA and integrating controlled size gold nanoparticles (AuNPs) to generate signals that could be detected from the users' naked eye. The system could sense only a few protein molecules by using the AuNPs that had a growthcontrolled monitor system. When the target proteins were bound, the AuNPs grew and resulted in a visible colored solution [68]. Specifically, the microtiter plate was modified with antibodies for protein enrichment. The streptavidincatalase conjugate was then added. Freshly prepared AuNPs were added to each well, and the absorbance at $550 \mathrm{~nm}$ was recorded after 15 min with a SpectraMax M5 plate reader. In order for the results to be visible to the naked eyes, the biocatalytic cycle of the enzyme label was related to the growth of the gold nanoparticles to obtain the blue or red colors in the presence or absence of the analyte, respectively. In the absence of the analyte, the reduction of gold ions with hydrogen peroxide occurred at a fast rate, and quasi-spherical, nonaggregated gold nanoparticles were obtained. Therefore, the red color was generated. In the presence of the analyte, the enzyme catalase consumed hydrogen peroxide. This slowed down the crystal growth, resulting in the growth of nanocrystals which showed an ill-defined morphology making up aggregated nanoparticles. Subsequently, the solution turned blue. This approach was tested on proteins PSA and p24 and achieved a LOD of $1 \times 10^{-6} \mathrm{pg} / \mathrm{mL}$ [68]. In addition to a low LOD, being able to immediately distinguish the presence or absence of analyte made the results of this method easily detectable without the need of a detector.

Gold nanoparticles have also been used with surfaceenhanced Raman scattering (SERS) to increase signal intensity for protein detection. Szekeres et al. used AuNP agglomerates to enhance SERS spectra detection when proteins reacted with the surface of the nanoparticles. The generated signal was
$10^{8}$ stronger when compared to that of normal Raman signals, giving this method the ability to achieve a high protein detection sensitivity [69]. To take advantage of this, Li et al. developed a multiplexed SERS detection using gold-silver nanoboxes for signal enhancement. A panel of soluble cancer protein markers, such as soluble programmed death 1 (sPD-1), soluble programmed death-ligand 1 (sPD-L1), and soluble epithermal growth factor receptor (sEGFR), were detected. In the assay, gold-silver alloy nanoboxes which had strong Raman signal enhancement capability were used as plasmonic nanostructures to allow for sensitive detection. A lower LOD of $0.68 \mathrm{pg} / \mathrm{mL}$ was reached for these cancer markers in serum, superior than those of ELISA [3]. This demonstrated that not only nanoparticles but also other nanostructures can be used to enhance the signals of protein detection.

\section{Perspectives and conclusion}

Table 1 shows the main methods and performance of various technologies used to enhance the antibody-based protein assay sensitivity. Notably, several technologies have achieved LODs at low fg/mL in complex samples, outperforming conventional ELISA by $2-3$ orders of magnitude. All the listed methods were appropriate to measure proteins in complex biofluids such as blood serum without the need of sample purification. In terms of the detection methods, fluorescencebased detection has been commonly used, probably due to its strong signal, widely available reagents, multiplexing capability, and easily accessible microscopy instruments. Other methods such as those based on electrical, colorimetric, or non-labeling optical signals have also been innovated for improved assay sensitivity. Many methods have been multiplexed to meet the needs of biomedical applications. Although some techniques still required hours to complete, which is similar to that of conventional ELISA, many of these assay processes can be potentially shortened by integrating with microfluidic systems. However, most of the listed techniques required relatively complex micro-/nano-fabrication processes and specialized instruments, constituting a major challenge for broader applications.

In this article, we have discussed various strategies for improving protein assay sensitivity including assay miniaturization, increased antibody binding capacity, sample purification, and signal amplification. We categorized these technologies following the typical procedure of a sandwich immunoassay, i.e., capture antibody immobilization, sample incubation, addition of a secondary antibody, and signal detection. Every step of the assay can be innovated to enhance assay sensitivity. From another perspective, we could also group these technologies based on if they improve SNR by strengthening specific assay signals, or by minimizing noise. Among these strategies, 
Table 1 Methods and results of the selected technologies for improving the sensitivity of the protein assays

\begin{tabular}{|c|c|c|c|c|c|c|c|}
\hline Technique & Sample & $\begin{array}{l}\text { Detection } \\
\text { methods }\end{array}$ & LODs & Multiplexed? & Assay time & $\begin{array}{l}\text { Main instrument } \\
\text { or reagent }\end{array}$ & Pros/cons \\
\hline $\begin{array}{l}\text { Optically enhanced } \\
\text { protein } \\
\text { microarray [25] }\end{array}$ & Diluted serum & Amperometry & $10 \mathrm{fg} / \mathrm{mL}$ & Y & Hours & $\begin{array}{l}\text { Gold compact } \\
\text { discs }\end{array}$ & $\begin{array}{l}\text { Pros: High sensitivity, } \\
\text { simplicity } \\
\text { Cons: Requires gold discs }\end{array}$ \\
\hline $\begin{array}{l}\text { dELISA with } \\
\text { micro-beads } \\
{[40]}\end{array}$ & Serum & Fluorescence & $\begin{array}{l}\sim 10-20 \\
\quad \text { enzyme-labeled } \\
\text { complexes in } \\
100 \mathrm{~mL} \text { of } \\
\text { sample }\end{array}$ & $\mathrm{Y}$ & Hours & dELISA setup & $\begin{array}{l}\text { Pros: High sensitivity, no } \\
\text { need for complex } \\
\text { equipment } \\
\text { Cons: Requires multiple } \\
\text { repetitive steps }\end{array}$ \\
\hline $\begin{array}{l}\text { Hydrogel } \\
\text { microparticle } \\
\text { immunoassay } \\
\text { [43] }\end{array}$ & Serum & Fluorescence & $17.7 \mathrm{pg} / \mathrm{mL}$ & $\mathrm{Y}$ & Hours & Microfluidic chip & $\begin{array}{l}\text { Pros: High sensitivity } \\
\text { Cons: Multiple assay steps } \\
\text { required }\end{array}$ \\
\hline $\begin{array}{l}\text { CNT-assembly } \\
\text { nanosensor [46] }\end{array}$ & Serum & Dielectrophoretic & $100 \mathrm{fM}$ & $\mathrm{N}$ & Hours & CNTs & $\begin{array}{l}\text { Pros: Low limit of detection } \\
\text { Cons: Requiring access to } \\
\text { carbon nanotubes } \\
\text { implemented on a gold } \\
\text { electrode }\end{array}$ \\
\hline $\begin{array}{l}\text { Beads-in-hydrogel } \\
\text { droplet } \\
\text { microarray [48] }\end{array}$ & Serum & Fluorescence & $<100 \mathrm{pg} / \mathrm{mL}$ & Y & Hours & $\begin{array}{l}\text { Microarray } \\
\text { scanner }\end{array}$ & $\begin{array}{l}\text { Pros: Multiplexing capacity, } \\
\text { low cost, and high } \\
\text { sensitivity } \\
\text { Cons: Requiring handling } \\
\text { with care during the assay } \\
\text { as hydrogel droplets are } \\
\text { fragile }\end{array}$ \\
\hline $\begin{array}{l}\text { Microfluidic } \\
\text { plasma } \\
\text { separation and } \\
\text { ELISA device } \\
\text { [55] }\end{array}$ & Whole blood & $\begin{array}{l}\text { Absorbance-based } \\
\text { optical detection }\end{array}$ & $0.7 \mathrm{ng} / \mathrm{mL}$ & Y & $22 \mathrm{~min}$ & $\begin{array}{l}\text { Microfluidic } \\
\text { ELISA device }\end{array}$ & $\begin{array}{l}\text { Pros: Analyzing whole blood } \\
\text { in a short amount of time, } \\
\text { high sensitivity, and } \\
\text { requiring small sample } \\
\text { volume } \\
\text { Cons: required } \\
\text { microfabrication }\end{array}$ \\
\hline $\begin{array}{l}\text { QDs-based protein } \\
\text { detection [59] }\end{array}$ & Cell media & Luminescence & 180 attomolar & Y & Hours & $\begin{array}{l}\text { A } \\
\text { spectrophotom- } \\
\text { eter }\end{array}$ & $\begin{array}{l}\text { Pros: achieved single-cell } \\
\text { level } \\
\text { Cons: required } \\
\text { microfabrication to isolate } \\
\text { single cells }\end{array}$ \\
\hline $\begin{array}{l}\text { Proximity ligation } \\
\text { assay [64] }\end{array}$ & Plasma & $\begin{array}{l}\text { Quantitative } \\
\text { real-time PCR } \\
\text { (q-PCR). }\end{array}$ & $3.1 \mathrm{pg} / \mathrm{mL}$ & Y & Mins-hours & $\begin{array}{l}\text { PLA probes, PCR } \\
\text { setup }\end{array}$ & $\begin{array}{l}\text { Pros: High sensitivity and } \\
\text { specify } \\
\text { Cons: Multiple steps in the } \\
\text { manufacturing and assay } \\
\text { procedure required }\end{array}$ \\
\hline $\begin{array}{l}\text { Fiber optic SPR } \\
\text { probe for } \\
\text { immunoassay } \\
{[67]}\end{array}$ & Serum & $\begin{array}{l}\text { Surface plasmon } \\
\text { resonance } \\
\text { (SPR) }\end{array}$ & $0.1 \mu \mathrm{g} / \mathrm{mL}$ & $\mathrm{N}$ & Mins-hours & SPR biosensors & $\begin{array}{l}\text { Pros: High sensitivity, } \\
\text { simplicity, } \\
\text { miniaturization, and low } \\
\text { cost } \\
\text { Cons: Required } \\
\text { microfabrication process }\end{array}$ \\
\hline $\begin{array}{l}\text { Gold and silver } \\
\text { nanoboxes with } \\
\text { SERS [3] }\end{array}$ & Serum & $\begin{array}{l}\text { SERS with } \\
\text { nanotags }\end{array}$ & $0.68 \mathrm{pg} / \mathrm{mL}$ & Y & Mins-hours & $\begin{array}{l}\text { UV-vis } \\
\text { spectrophotom- } \\
\text { eter }\end{array}$ & $\begin{array}{l}\text { Pros: High sensitivity and } \\
\text { multiplexity } \\
\text { Cons: Required access to } \\
\text { gold-silver nanoboxes }\end{array}$ \\
\hline $\begin{array}{l}\text { Affinity-MS } \\
\text { assays [70] }\end{array}$ & Serum/plasma & MS & $\begin{array}{l}2 \mu \mathrm{g} \text { of total starting } \\
\text { protein from } \\
\text { digested cell } \\
\text { culture lysates }\end{array}$ & $\mathrm{Y}$ & Hours & $\begin{array}{l}\text { MALDI mass } \\
\text { spectrometer }\end{array}$ & $\begin{array}{l}\text { Pros: multiplexed, sensitive, } \\
\text { specific } \\
\text { Cons: Required a high-end } \\
\text { MALDI mass spectrome- } \\
\text { ter }\end{array}$ \\
\hline
\end{tabular}

sample purification reduces the amount of other molecules in a sample solution to decrease the non-specific binding scenarios, hence lowering noise signals. Improving the antibody binding capacity and signal amplification could improve assay signals, but the specificity depends on the quality and specificity of the antibody.

Indeed, antibody is one of the most important players for immunoassay-based protein quantification. The quality of the 
antibody will directly impact assay performance, regardless of the assay format or the platform used. An antibody with high antibody-antigen binding affinity and low dissociation constant will help improve the assay sensitivity. Moreover, a highly specific antibody will provide results with low nonspecific binding, improving assay sensitivity. However, the selection of appropriate antibodies can be a lengthy process [71]. Alternative options such as aptamers and nanobodies have been under investigation, and could be promising complementary approaches for protein quantification [72]. Other factors such as temperature, $\mathrm{pH}$, ionic strength, and duration of sample incubation are also important to achieve highly sensitive protein quantification.

Among the emerging strategies towards highly sensitive protein assays, LOC technologies and nanomaterials have taken and will continue to take an important role. For example, some micro-chips and micro-bead-based methods such as dELISA have achieved detection at low $\mathrm{fg} / \mathrm{mL}$ sensitivity in complexed biofluids. With novel nanomaterials as signal reporters, sub-pg/mL sensitivity has been reached. All these efforts required multidisciplinary knowledge and skills integrating biology, chemistry, and engineering. In addition, bioinformatics is usually needed for large-scale protein detection technologies, e.g., microarrays and high-throughput biochips. Furthermore, it is noted that many of the methods we have covered combined several strategies in the same platform to achieve optimal assay results. It is clear that collaboration with researchers from different academic backgrounds is beneficial in this research field.

Interestingly, as shown in Table 1, most of these emerging technologies were tested with blood serum samples. Blood is enriched with proteins and can provide comprehensive information due to body circulation; therefore, it has attracted extensive research interests. Other biofluids such as urine and saliva deserve more investigations for their potential biomedical applications, considering the relatively easy and noninvasive collection of these samples.

It is worth mentioning that micro- and nanotechnologies have been used for not only antibody-based immunoassays, but also affinity-MS assays [70, 73]. For example, miniaturized sample spots combined with MALDI MS have achieved low LODs in the $\mathrm{fg} / \mathrm{mL}$ range, outperforming conventional MS technologies. These efforts have been reviewed by $\mathrm{Tu}$ et al. [74] so we are not going to discuss more details in this article.

In addition to sensitivity, multiplexing capacity and short turnaround time are also critical for certain applications, e.g., biomarker discovery and rapid tests. With miniaturization, integration, and parallelization, some of the emerging technologies have achieved good performance on all these three aspects. To improve the overall assay performance, multiple strategies can be integrated into a single system as we saw in earlier examples.
Furthermore, these sensing technologies have been recently applied in the fight against COVID-19 pandemic. Since this topic has been well reviewed recently, we will not discuss it in detail. For example, Shaffaf et al. reviewed protein-based technologies for the diagnostics of COVID-19 [75]. Affinity sensors for diagnosis has been discussed by Drobysh et al. [76]. Shetti et al. described conventional and nanotechnology-based sensors for COVID-19 [77]. Recent efforts in the applications of colloidal particles and nanoparticles for the diagnostics and treatment of COVID-19 have also been summarized [78, 79]. Kotru et al. reviewed electrochemical sensing technologies prognostics purposes [80]. Song et al. discussed recent strategies towards point-of-care testing detection technologies [81].

Last but not least, although the focus of this article is on protein quantification, other omics studies such as genomics, metabolomics, cellomics, and exomics have also shown important clinical implications [82-87]. Indeed, many of the strategies on sensitive protein detection could be adapted for quantifying other biomolecules, vesicles, or cells. Furthermore, novel technologies enabling multi-omics studies will provide more comprehensive information on physiological and pathological processes, contributing to global health.

Acknowledgements We thank the financial support from the University of Guelph (UofG) to complete this work. T.C acknowledges a research assistantship supported by UofG. N. M. thanks UofG for a graduate fellowship.

Funding The authors received financial support from the University of Guelph (UofG) to complete this work.

\section{Declarations}

Conflict of interest The authors declare no competing interests.

\section{References}

1. Bashir H, Wani BA, Ganai BA, Mir SA. Protein glycosylation: an important tool for diagnosis or early detection of diseases. In: Protein Modificomics. pp 339-359;2019. https://doi.org/10.1016/ b978-0-12-811913-6.00013-8

2. Ruhen O, Meehan K. Tumor-derived extracellular vesicles as a novel source of protein biomarkers for cancer diagnosis and monitoring. Proteomics. 2019;19(1-2):e1800155. https://doi.org/10. 1002/pmic. 201800155.

3. Li J, Wang J, Grewal YS, Howard CB, Raftery LJ, Mahler S, et al. Trau M Multiplexed SERS detection of soluble cancer protein biomarkers with gold-silver alloy nanoboxes and nanoyeast singlechain variable fragments. Anal Chem. 2018;90(17):10377-84. https://doi.org/10.1021/acs.analchem.8b02216.

4. Wu C, Garden PM. Walt DR Ultrasensitive detection of attomolar protein concentrations by dropcast single molecule assays. J Am Chem Soc. 2020;142(28):12314-23. https://doi.org/10.1021/jacs. $0 \mathrm{c} 04331$. 
5. Trofymchuk K, Glembockyte V, Grabenhorst L, Steiner F, Vietz C, Close C, et al. Tinnefeld P Addressable nanoantennas with cleared hotspots for single-molecule detection on a portable smartphone microscope. Nat Commun. 2021;12(1):950. https://doi.org/10. 1038/s41467-021-21238-9.

6. Dagogo-Jack I. Shaw AT Tumour heterogeneity and resistance to cancer therapies. Nat Rev Clin Oncol. 2018;15(2):81-94. https:// doi.org/10.1038/nrclinonc.2017.166.

7. Caswell DR. Swanton C The role of tumour heterogeneity and clonal cooperativity in metastasis, immune evasion and clinical outcome. BMC Med. 2017;15(1):133. https://doi.org/10.1186/ s12916-017-0900-y.

8. Yang X, Tang Y, Alt RR, Xie X. Li F Emerging techniques for ultrasensitive protein analysis. Analyst. 2016;141(12):3473-81. https://doi.org/10.1039/c6an00059b.

9. Hori SS, Gambhir SS. Mathematical model identifies blood biomarker-based early cancer detection strategies and limitations. Sci Transl Med. 2011;3(109):109ra116-01. https://doi.org/10. 1126/scitranslmed.3003110.

10. Hu R, Sou K, Takeoka S. A rapid and highly sensitive biomarker detection platform based on a temperature-responsive liposomelinked immunosorbent assay. Sci Rep. 2020;10(1). https://doi.org/ 10.1038/s41598-020-75011-x.

11. Cardozo KHM, Lebkuchen A, Okai GG, Schuch RA, Viana LG, Olive AN. Lazari CdS, Fraga AM, Granato CFH, Pintão MCT, Carvalho VM Establishing a mass spectrometry-based system for rapid detection of SARS-CoV-2 in large clinical sample cohorts. Nat Commun. 2020;11(1):6201. https://doi.org/10.1038/s41467020-19925-0.

12. Higashi SL, Yagyu K, Nagase H, Pearson CS, Geller HM, Katagiri Y. Ultra-high-speed western blot using immunoreaction enhancing technology. JoVE. 2020;(163):e61657. https://doi.org/10.3791/ 61657.

13. Smeraglia J, Silva J-P. Jones K Improving the sensitivity and specificity of a bioanalytical assay for the measurement of certolizumab pegol. Bioanalysis. 2017;9(16):1217-26. https://doi.org/10.4155/ bio-2017-0124.

14. Chen Y-J, Chen M, Hsieh Y-C, Su Y-C, Wang C-H, Cheng C-M, et al. Development of a highly sensitive enzyme-linked immunosorbent assay (ELISA) through use of poly-protein G-expressing cell-based microplates. Sci Rep. 2018;8(1). https://doi.org/10.1038/ s41598-018-36192-8.

15. Abe Y, Hasegawa T, Yamasita M. Micro ELISA chip to detect multiple allergic proteins simultaneously. In: 2019 IEEE/SICE International Symposium on System Integration (SII), 14-16 Jan. 2019; 2019. pp 675-678. https://doi.org/10.1109/SII.2019. 8700438

16. Bosco A, Ambrosetti E, Mavri J, Capaldo P, Casalis L. Miniaturized aptamer-based assays for protein detection. Chemosensors. 2016;4(3). https://doi.org/10.3390/ chemosensors4030018.

17. Uddin MJ, Bhuiyan NH. Shim JS Fully integrated rapid microfluidic device translated from conventional 96-well ELISA kit. Sci Rep. 2021;11(1):1986. https://doi.org/10.1038/s41598021-81433-y.

18. Weng L. Spoonamore JE Droplet microfluidics-enabled highthroughput screening for protein engineering. Micromachines. 2019;10(11):734. https://doi.org/10.3390/mi10110734.

19. Li H, Bergeron S, Larkin H, Juncker D. Snap chip for crossreactivity-free and spotter-free multiplexed sandwich immunoassays. JoVE. 2017;(129):e56230. https://doi.org/10.3791/56230.

20. Li H, Brewer G, Ongo G, Normandeau F, Omeroglu A. Juncker D Immunohistochemistry microarrays. Anal Chem. 2017;89(17): 8620-5. https://doi.org/10.1021/acs.analchem.7b00807.

21. Kalli M, Blok A, Jiang L, Starr N, Alcocer MJC. Falcone FH Development of a protein microarray-based diagnostic chip mimicking the skin prick test for allergy diagnosis. Sci Rep. 2020;10(1):18208. https://doi.org/10.1038/s41598-020-75226-y.

22. Chen Z, Dodig-Crnković T, Schwenk JM. Tao S-c Current applications of antibody microarrays. Clin Proteomics. 2018;15(1):7. https://doi.org/10.1186/s12014-018-9184-2.

23. Neagu M, Bostan M. Constantin C Protein microarray technology: assisting personalized medicine in oncology (Review). World Acad Sci J. 2019;1(3):113-24. https://doi. org/10.3892/wasj.2019.15.

24. Delfani P, Dexlin Mellby L, Nordström M, Holmér A, Ohlsson M, Borrebaeck CAK. Wingren C Technical advances of the recombinant antibody microarray technology platform for clinical immunoproteomics. PLoS One. 2016;11(7):e0159138. https://doi. org/10.1371/journal.pone.0159138.

25. Zhang D, Dai W, Hu H, Chen W, Liu Y, Guan Z, et al. Xu H Controlling the immobilization process of an optically enhanced protein microarray for highly reproducible immunoassay. Nanoscale. 2021;13(7):4269-77. https://doi.org/10.1039/ d0nr08407g.

26. Jeong Y, Kook Y-M, Lee K, Koh W-G. Metal enhanced fluorescence (MEF) for biosensors: general approaches and a review of recent developments. Biosens Bioelectron. 2018;111:102-16. https://doi.org/10.1016/j.bios.2018.04.007.

27. Verardo D, Liljedahl L, Richter C, Agnarsson B, Axelsson U, Prinz $\mathrm{CN}$, et al. Linke H Fluorescence signal enhancement in antibody microarrays using lightguiding nanowires. Nanomaterials. 2021;11(1):227. https://doi.org/10.3390/nano1 1010227.

28. Li J, Cai T, Li W, Li W, Song L, Li Q, et al. Zheng T Highly sensitive simultaneous detection of multiple mycotoxins using a protein microarray on a $\mathrm{TiO} 2$-modified porous silicon surface. $\mathrm{J}$ Agric Food Chem. 2021;69(1):528-36. https://doi.org/10.1021/ acs.jafc.0c06859.

29. Gao D, Jin F, Zhou M, Jiang Y. Recent advances in single cell manipulation and biochemical analysis on microfluidics. Analyst. 2019;144. https://doi.org/10.1039/c8an01186a.

30. Tavakoli H, Zhou W, Ma L, Perez S, Ibarra A, Xu F, et al. Recent advances in microfluidic platforms for single-cell analysis in cancer biology, diagnosis and therapy, vol. 117. Amsterdam: Elsevier B.V.; 2019. https://doi.org/10.1016/j.trac.2019.05.010.

31. Shadfan BH, Simmons AR, Simmons GW, Ho A, Wong J, Lu KH, et al. McDevitt JT A multiplexable, microfluidic platform for the rapid quantitation of a biomarker panel for early ovarian cancer detection at the point-of-care. Cancer Prev Res. 2015;8(1):37-48. https://doi.org/10.1158/1940-6207.CAPR-14-0248.

32. D'Souza AL, Chevillet JR, Ghanouni P, Yan X, Tewari M. Gambhir SS Tumor characterization by ultrasound-release of multiple protein and microRNA biomarkers, preclinical and clinical evidence. PLoS One. 2018;13(3):e0194268. https://doi.org/10. 1371/journal.pone.0194268.

33. Mosaad EO, Chambers KF, Futrega K, Clements JA. Doran MR The Microwell-mesh: a high-throughput 3D prostate cancer spheroid and drug-testing platform. Sci Rep. 2018;8(1):253. https://doi. org/10.1038/s41598-017-18050-1.

34. Abali F, Broekmaat J, Tibbe A, Schasfoort RBM, Zeune L. Terstappen LWMM A microwell array platform to print and measure biomolecules produced by single cells. Lab Chip. 2019;19(10):1850-9. https://doi.org/10.1039/C9LC00100J.

35. Choi J, Routenberg Love K, Gong Y, Gierahn TM. Love JC Immuno-hybridization chain reaction for enhancing detection of individual cytokine-secreting human peripheral mononuclear cells. Anal Chem. 2011;83(17):6890-5. https://doi.org/10.1021/ ac2013916.

36. Byrnes SA, Huynh T, Chang TC, Anderson CE, McDermott JJ, Oncina CI, et al. Nichols KP Wash-free, digital immunoassay in polydisperse droplets. Anal Chem. 2020;92(5):3535-43. https:// doi.org/10.1021/acs.analchem.9b02526. 
37. Stuelke EL, James KS, Kirchherr JL, Allard B, Baker C, Kuruc JD, et al. Archin NM Measuring the inducible, replication-competent HIV reservoir using an ultra-sensitive p24 readout, the digital ELISA viral outgrowth assay. Front Immunol. 2020;11:1971.

38. Rissin DM, Kan CW, Campbell TG, Howes SC, Fournier DR, Song L, et al. Duffy DC Single-molecule enzyme-linked immunosorbent assay detects serum proteins at subfemtomolar concentrations. Nat Biotechnol. 2010;28(6):595-9. https://doi.org/10.1038/ nbt.1641.

39. Yelleswarapu V, Buser JR, Haber M, Baron J, Inapuri E. Issadore D Mobile platform for rapid sub-picogram-per-milliliter, multiplexed, digital droplet detection of proteins. Proc Natl Acad Sci U S A. 2019;116(10):4489-95. https://doi.org/10.1073/pnas.1814110116.

40. Akama K, Shirai K. Suzuki S Droplet-free digital enzyme-linked immunosorbent assay based on a tyramide signal amplification system. Anal Chem. 2016;88(14):7123-9. https://doi.org/10.1021/acs. analchem.6b01148.

41. Huang JY, Lin HT, Chen TH, Chen CA, Chang HT. Chen CF Signal amplified gold nanoparticles for cancer diagnosis on paperbased analytical devices. ACS Sens. 2018;3(1):174-82. https://doi. org/10.1021/acssensors. 7b00823.

42. Huergo LF, Selim KA, Conzentino MS, Gerhardt ECM, Santos ARS, Wagner B, et al. Forchhammer K Magnetic bead-based immunoassay allows rapid, inexpensive, and quantitative detection of human SARS-CoV-2 antibodies. ACS Sens. 2021;6(3):703-8. https://doi.org/10.1021/acssensors.0c02544.

43. Lee HJ, Roh YH, Kim HU, Kim SM. Bong KW Multiplexed immunoassay using post-synthesis functionalized hydrogel microparticles. Lab Chip. 2019;19(1):111-9. https://doi.org/10.1039/ C8LC01160E.

44. Snider EJ, Crowley AR, Raykin J, Kim RK, Splaine F. Ethier CR A flexible, robust microbead-based assay for quantification and normalization of target protein concentrations. Anal Biochem. 2020;590:113510. https://doi.org/10.1016/j.ab.2019.113510.

45. Lin YH, Peng PY. Semiconductor sensor embedded microfluidic chip for protein biomarker detection using a bead-based immunoassay combined with deoxyribonucleic acid strand labeling. Anal Chim Acta. 2015;869:34-42. https://doi.org/10.1016/j.aca.2015. 03.002 .

46. van den Broek I, Fu Q, Kushon S, Kowalski MP, Millis K, Percy A, et al. Application of volumetric absorptive microsampling for robust, high-throughput mass spectrometric quantification of circulating protein biomarkers. Clin Mass Spectrom. 2017;4-5:25-33. https://doi.org/10.1016/j.clinms.2017.08.004.

47. Zhang P, Zhou X, He M, Shang Y, Tetlow AL, Godwin AK. Zeng $\mathrm{Y}$ Ultrasensitive detection of circulating exosomes with a 3Dnanopatterned microfluidic chip. Nat Biomed Eng. 2019;3(6): 438-51. https://doi.org/10.1038/s41551-019-0356-9.

48. Li H, Leulmi RF. Juncker D Hydrogel droplet microarrays with trapped antibody-functionalized beads for multiplexed protein analysis. Lab Chip. 2011;11(3):528-34. https://doi.org/10.1039/ c01c00291g.

49. Adami VS. Verschoore JR Implications of network relations for the governance of complex projects. Proj Manag J. 2018;49(2):71-88. https://doi.org/10.1177/875697281804900205.

50. Shen M, Chen Y, Zhu Y, Zhao M. Xu Y Enhancing the sensitivity of lateral flow immunoassay by centrifugation-assisted flow control. Anal Chem. 2019;91(7):4814-20. https://doi.org/10.1021/acs. analchem.9b00421.

51. Sena-Torralba A, Ngo DB, Parolo C, Hu L, Álvarez-Diduk R, Bergua JF, et al. Merkoçi A Lateral flow assay modified with time-delay wax barriers as a sensitivity and signal enhancement strategy. Biosens Bioelectron. 2020;168:112559. https://doi.org/ 10.1016/j.bios.2020.112559.

52. Shimizu H, Kumagai M, Mori E, Mawatari K. Kitamori T Whole blood analysis using microfluidic plasma separation and enzyme- linked immunosorbent assay devices. Anal Methods. 2016;8(42): 7597-602. https://doi.org/10.1039/c6ay01779g.

53. Tadimety A, Closson A, Li C, Yi S, Shen T. Zhang JXJ Advances in liquid biopsy on-chip for cancer management: technologies, biomarkers, and clinical analysis. Crit Rev Clin Lab Sci. 2018;55(3): 140-62. https://doi.org/10.1080/10408363.2018.1425976.

54. Qin L, Vermesh O, Shi Q. Heath JR Self-powered microfluidic chips for multiplexed protein assays from whole blood. Lab Chip. 2009;9(14):2016-20. https://doi.org/10.1039/b821247c.

55. Lee BS, Lee YU, Kim HS, Kim TH, Park J, Lee JG, et al. Cho YK Fully integrated lab-on-a-disc for simultaneous analysis of biochemistry and immunoassay from whole blood. Lab Chip. 2011;11(1):70-8. https://doi.org/10.1039/c0lc00205d.

56. Woo HK, Sunkara V, Park J, Kim TH, Han JR, Kim CJ, et al. Cho YK Exodisc for rapid, size-selective, and efficient isolation and analysis of nanoscale extracellular vesicles from biological samples. ACS Nano. 2017;11(2):1360-70. https://doi.org/10.1021/ acsnano.6b06131.

57. Chen P, Chen D, Li S, Ou X, Liu BF. Microfluidics towards single cell resolution protein analysis. TrAC Trends Anal Chem. 2019;117:2-12. https://doi.org/10.1016/j.trac.2019.06.022.

58. Yu X, Wu N, Chen F, Wei J, Zhao Y. Engineering microfluidic chip for circulating tumor cells: from enrichment, release to single cell analysis, vol. 117. Amsterdam: Elsevier B.V.; 2019. https://doi. org/10.1016/j.trac.2019.03.027.

59. Herrera V, Hsu SCJ, Rahim MK, Chen C, Nguyen L, Liu WF. Haun JB Pushing the limits of detection for proteins secreted from single cells using quantum dots. Analyst. 2019;144(3):980-9. https://doi.org/10.1039/c8an01083h.

60. Gong X, Yan H, Yang J, Wu Y, Zhang J, Yao Y, et al. Highperformance fluorescence-encoded magnetic microbeads as microfluidic protein chip supports for AFP detection. Anal Chim Acta. 2016;939:84-92. https://doi.org/10.1016/j.aca.2016.08.031.

61. Tang M, Pi J, Long Y, Huang N, Cheng Y, Zheng H. Quantum dots-based sandwich immunoassay for sensitive detection of Alzheimer's disease-related A $\beta 1-42$. Spectrochim Acta A Mol Biomol Spectrosc. 2018;201:82-7. https://doi.org/10.1016/j.saa. 2018.04.060.

62. Alam MS. Proximity Ligation Assay (PLA). Curr Protoc Immunol. 2018;123(1):e58. https://doi.org/10.1002/cpim.58.

63. Klaesson A, Grannas K, Ebai T, Heldin J, Koos B, Leino M, et al. Landegren U Improved efficiency of in situ protein analysis by proximity ligation using UnFold probes. Sci Rep. 2018;8(1):5400. https://doi.org/10.1038/s41598-018-23582-1.

64. Castro-López V, Elizalde J, Pacek M, Hijona E, Bujanda L. A simple and portable device for the quantification of TNF- $\alpha$ in human plasma by means of on-chip magnetic bead-based proximity ligation assay. Biosens Bioelectron. 2014;54:499-505. https://doi. org/10.1016/j.bios.2013.10.039.

65. Darmanis S, Nong RY, Hammond M, Gu J, Alderborn A, Vänelid J, et al. Kamali-Moghaddam M Sensitive plasma protein analysis by microparticle-based proximity ligation assays. Mol Cell Proteomics. 2010;9(2):327-35. https://doi.org/10.1074/mcp. M900248-MCP200.

66. Min J, Son T, Hong J-S, Cheah PS, Wegemann A, Murlidharan K, et al. Im H Plasmon-enhanced biosensing for multiplexed profiling of extracellular vesicles. Adv Biosyst. 2020;4(12):2000003. https:// doi.org/10.1002/adbi.202000003.

67. Mai Z, Zhang J, Chen Y, Wang J, Hong X, Su Q. Li X A disposable fiber optic SPR probe for immunoassay. Biosens Bioelectron. 2019;144:111621. https://doi.org/10.1016/j.bios.2019.111621.

68. De La Rica R. Stevens MM Plasmonic ELISA for the ultrasensitive detection of disease biomarkers with the naked eye. Nat Nanotechnol. 2012;7(12):821-4. https://doi.org/10.1038/nnano. 2012.186 . 
69. Foti A, D'Andrea C, Villari V, Micali N, Donato MG, Fazio B, et al. Optical aggregation of gold nanoparticles for SERS detection of proteins and toxins in liquid environment: towards ultrasensitive and selective detection. Materials. 2018;11(3). https://doi.org/10. 3390/ma11030440.

70. Hamza GM, Bergo VB, Mamaev S, Wojchowski DM, Toran P, Worsfold CR, et al. Affinity-bead assisted mass spectrometry (Affi-BAMS): a multiplexed microarray platform for targeted proteomics. Int J Mol Sci. 2020;21(6). https://doi.org/10.3390/ ijms21062016.

71. Pillai-Kastoori L, Heaton S, Shiflett SD, Roberts AC, Solache A. Schutz-Geschwender AR Antibody validation for Western blot: by the user, for the user. J Biol Chem. 2020;295(4):926-39. https://doi. org/10.1074/jbc.RA119.010472.

72. Dhar P, Samarasinghe RM, Shigdar S. Antibodies, nanobodies, or aptamers - which is best for deciphering the proteomes of nonmodel species? Int J Mol Sci. 2020;21(7). https://doi.org/10.3390/ ijms21072485.

73. Li H, Popp R, Borchers CH. Affinity-mass spectrometric technologies for quantitative proteomics in biological fluids. TRAC-Trend Anal Chem. 2017;90:80-8. https://doi.org/10.1016/j.trac.2017.02. 011.

74. Tu T. Gross ML Miniaturizing sample spots for matrix-assisted laser desorption/ionization mass spectrometry. TRAC-Trend Anal Chem. 2009;28(7):833-41. https://doi.org/10.1016/j.trac.2009.03. 013.

75. Shaffaf T, Ghafar-Zadeh E. COVID-19 diagnostic strategies part II: protein-based technologies. Bioengineering. 2021;8(5). https://doi. org/10.3390/bioengineering8050054.

76. Drobysh M, Ramanaviciene A, Viter R, Ramanavicius A. Affinity sensors for the diagnosis of COVID-19. Micromachines. 2021;12(4). https://doi.org/10.3390/mi12040390.

77. Shetti NP, Mishra A, Bukkitgar SD, Basu S, Narang J, Raghava Reddy K. Aminabhavi TM Conventional and nanotechnologybased sensing methods for SARS coronavirus (2019-nCoV). ACS Appl Bio Mater. 2021;4(2):1178-90. https://doi.org/10.1021/ acsabm.0c01545.

78. Dheyab MA, Khaniabadi PM, Aziz AA, Jameel MS, Mehrdel B, Oglat AA. Khaleel HA Focused role of nanoparticles against
COVID-19: diagnosis and treatment. Photodiagn Photodyn Ther. 2021;34:102287. https://doi.org/10.1016/j.pdpdt.2021.102287.

79. Saatçi E, Natarajan S. State-of-the-art colloidal particles and unique interfaces-based SARS-CoV-2 detection methods and COVID-19 diagnosis. Curr Opin Colloid Interface Sci. 2021;55:101469. https://doi.org/10.1016/j.cocis.2021.101469.

80. Kotru S, Klimuntowski M, Ridha H, Uddin Z, Askhar AA, Singh G. Howlader MMR electrochemical sensing: a prognostic tool in the fight against COVID-19. Trends Anal Chem. 2021;136: 116198. https://doi.org/10.1016/j.trac.2021.116198.

81. Song Q, Sun X, Dai Z, Gao Y, Gong X, Zhou B, et al. Wen W Point-of-care testing detection methods for COVID-19. Lab Chip. 2021;21(9):1634-60. https://doi.org/10.1039/D0LC01156H.

82. McGuire AL, Gabriel S, Tishkoff SA, Wonkam A, Chakravarti A, Furlong EEM, et al. Kim J-S The road ahead in genetics and genomics. Nat Rev Genet. 2020;21(10):581-96. https://doi.org/10.1038/ s41576-020-0272-6.

83. Segers K, Declerck S, Mangelings D, Heyden YV. Eeckhaut AV Analytical techniques for metabolomic studies: a review. Bioanalysis. 2019;11(24):2297-318. https://doi.org/10.4155/bio2019-0014.

84. Deng Y, Finck A. Fan R Single-cell omics analyses enabled by microchip technologies. Annu Rev Biomed Eng. 2019;21(1):36593. https://doi.org/10.1146/annurev-bioeng-060418-052538.

85. Zhang Y, Liu Y, Liu H. Tang WH Exosomes: biogenesis, biologic function and clinical potential. Cell Biosci. 2019;9(1):19. https:// doi.org/10.1186/s13578-019-0282-2.

86. Hou R, Li Y, Sui Z, Yuan H, Yang K, Liang Z, et al. Zhang Y Advances in exosome isolation methods and their applications in proteomic analysis of biological samples. Anal Bioanal Chem. 2019;411(21):5351-61. https://doi.org/10.1007/s00216-01901982-0.

87. Zhang L, Gu C, Wen J, Liu G, Liu H. Li L Recent advances in nanomaterial-based biosensors for the detection of exosomes. Anal Bioanal Chem. 2021;413(1):83-102. https://doi.org/10.1007/ s00216-020-03000-0.

Publisher's note Springer Nature remains neutral with regard to jurisdictional claims in published maps and institutional affiliations. 